\title{
European Journal of Social Psychology
}

\section{Using Nostalgia to Reduce Immigration Prejudice}

\begin{tabular}{|r|l|}
\hline Journal: & European Journal of Social Psychology \\
\hline Manuscript ID & EJSP-16-0193.R2 \\
\hline Wiley - Manuscript type: & Short Paper \\
\hline \multicolumn{2}{l}{} \\
\hline
\end{tabular}

SCHOLARONE ${ }^{m}$

Manuscripts 
Nostalgia and prejudice reduction

\section{Introduction}

Nostalgia is described as a sentimental longing or wistful affection for a period in the past (Oxford Dictionary of English, 1998). It is experienced by almost everyone at least three times a week (Boym, 2001; Hepper, Wildschut, Sedikides, Ritchie, Yung, et al., 2013; Wildschut, Sedikides, Arndt, \& Routledge, 2006). The word "nostalgia" has its roots in the Greek words "nostos", which is the return to one's native land, and "algos" that means pain. Thus, nostalgia literally means suffering from the longing to return home (Hepper, Sedikides, \& Wildschut, 2012). The word was originally used in Homer's Odyssey, in which the central hero Odysseus suffers emotionally from being away from his home and it is his memories of it that sustain and galvanize him (Austin, 2010). Thus, since ancient years, contemplating about one's past, especially the memories of close ones, was thought to motivate and strengthen people.

In the intergroup processes literature, emerging research suggests that nostalgia can be used to reduce the stigma faced by overweight people and people with mental health issues (Turner, Wildschut, \& Sedikides, 2011; Turner, Wildschut, \& Sedikides , 2012; Turner, Wildschut, Sedikides, \& Gheorghiu, 2013). With this as a starting point, the aim of the present study is to investigate the effects of nostalgia about an in-group immigrant on stigmatizing attitudes toward out-group immigrants. No research has yet tested the effects of nostalgia on counteracting immigrants' stigmatization, which has negative consequences on immigrants' mental and physical health (Walsh \& Walsh, 1986). Furthermore, this is to our knowledge the first study that examines whether induced nostalgia about an in-group member generalizes positivity to out-group members.

The study was conducted in Greece, a country that in the last two decades has suddenly received a very large number of immigrants from Balkan, African and Middle Eastern countries. Both the government and the society were unprepared to deal with this 
Nostalgia and prejudice reduction

change in demographics. According to Eurostat (2016), there are approximately 956,000 foreign nationals that reside in Greece as immigrants and asylum seekers, constituting $8.9 \%$ of the total Greek population in 2013 . Greece has been blamed for its inability to stop irregular migration and its particularly problematic asylum system (Triandafyllidou \& Ambrosini, 2011). In 2011 it was reported that $90 \%$ of all irregular entry in Europe was through the Greek borders (Kakkisis, 2014). In addition, Greece was also reported to have poor internal control over the labor market, an area where most immigrants are usually employed (Triandafyllidou \& Ambrosini, 2011). In this context, racism and xenophobia have been on the rise (Cholezasa \& Tsakloglou, 2009).

Immigrants have been typically viewed as a vulnerable group that belongs to the lowest economic layers in Greece (Tsitselikis, 2013). They are also labeled as non-citizens and therefore have limited societal rights (Tsitselikis, 2013). People's attitudes toward immigrants are quite negative, with $61 \%$ of Greeks believing that immigrants do not enrich Greece culturally, and $80 \%$ reporting that the presence of immigrants increases insecurity (Figgou, Sapountzis, Bozatzis, Gardikiotis, \& Pantazis, 2011). As such, improving attitudes toward immigrants is a topical issue, highly pertinent to Greece but also to the European context.

In recent years the predominantly positive effects that nostalgia has for individuals have been demonstrated (Cheung, Wildschut, Sedikides, Hepper, Arndt, \& Vingerhoets 2013). Nostalgia has been linked with bolstering social bonds, increasing positive self regard, generating positive affect, increasing optimism levels and alleviating existential threat (Cheung et al, 2013; Sedikides \& Arndt, 2006). Additionally, Sedikides, Wildschut, Arndt, \& Routledge, 2008) suggested that nostalgia increases self-esteem, inspiration and goal pursuit. Moreover, the positive effects of nostalgia have been linked with triggering empathy. Cordaro (2011) further found that participants, who recalled a nostalgic event 
Nostalgia and prejudice reduction

reported significantly higher levels of empathy than those who recalled an ordinary event.

Both nostalgia and empathy have been used as means to improve out-group attitudes. However, there is a basic difference between the manipulation of nostalgia and the manipulation of empathy. In our study, in line with previous nostalgia manipulations (Turner, Wildschut, \& Sedikides, 2012; Turner et al., 2013) we asked participants to think and write down a nostalgic event they have experienced with a close immigrant, while keeping their individual identity. Literature on empathy and attitudes, however, has shown that empathy manipulations are normally induced by asking participants to put themselves in another person's shoes and feel as if they were the person (of the ourgroup) themselves (Batson, Polycarpou, Harmon-Jones, Imhoff, Mitchener et al,1997; Clore \& Jeffrey,1972)

Another major function of nostalgia is that of enhancing an "expansive" state of mind that causes people to open up to the possibility of forming new relationships (Stephan, Sedikides, Wildschut, Routledge, Zhou et al, 2011). Allport (1954) suggested that the reverie of nostalgic memories triggers a vivid sense of commonality, where barriers have previously existed. When individuals feel nostalgic about a close out-group member, the out-group member shifts closer to the self (Turner et al., 2013). In a salient membership context, inclusion of an out-group member in the self will lead to inclusion of the entire out-group that he/she represents in the self (Aron, Aron, Tudor, \& Nelson, 1991; Brown \& Hewstone, 2005). These findings are central to our study, which aims at improving attitudes toward immigrants by increasing the sense of social connectedness and inclusion of the out-group in the self. In our study, we argue that even nostalgia about an in-group member (a Greek immigrant abroad) can shift the out-group (foreign immigrants in Greece) closer to the self, following an increase in social connectedness. In other words, we suggest that feeling nostalgic about a close in-group member enhances social 


\section{European Journal of Social Psychology}

Nostalgia and prejudice reduction

connectedness and therefore increases the overlap between the self and the out-group, to the extent that the out-group shares a common identity with the in-group member (they are all immigrants). This process can then lead to improved out-group attitudes.

Nostalgic feelings about an out-group member have also been linked to triggering out-group trust, that implies positive expectations about others' behavior or intention (Turner et al., 2010). For example, Turner et al $(2013 ; 2012)$ found that people who were induced with nostalgia through a past recollection of a close overweight or mentally ill person, demonstrated greater out-group trust, inclusion of the out-group in the self and increased social connectedness, which then led to more positive attitudes toward their outgroup in comparison to the control group. In our research, we expect nostalgia about an ingroup member to impact out-group trust given the shared membership between the close in-group member and the out-group (i.e., they are all immigrants).

Most of the above-mentioned studies have tested the effects of nostalgia about an out-group member. Although the literature is limited, the results are promising and highlight the potential of nostalgia in reducing prejudice. However, the intergroup context in Turner et al.'s $(2011 ; 2013)$ research was rather mild since the target groups of overweight and mentally ill people were not particularly threatening for individuals. We argue that in a context of conflict or threat people may not readily recall a pleasant intergroup experience that they can feel nostalgic about. In addition, people may be reluctant to engage in an emotional experience that involves nostalgia due to high levels of intergroup anxiety, negative stereotyping or threat (Stephan \& Stephan, 2000).

When seeking to reduce the stigma of immigrants, we suggest that the effects of nostalgia may go beyond intergroup boundaries. That is, thinking nostalgically about a close in-group member (that is a member of the same national group) who has immigrated to different country can increase positivity towards the whole out-group (i.e., immigrants 
Nostalgia and prejudice reduction

in general). No study to date has tested the effects of being nostalgic about a close in-group member, specifically here feeling nostalgic about a Greek immigrant abroad, on out-group attitudes. We hypothesize that:

Hypothesis 1: Participants in the nostalgia condition will score higher than those in the control condition on social connectedness, inclusion of the out-group in the self, outgroup trust, and out-group attitudes.

Hypothesis 2: The effects of nostalgia on out-group attitudes will be mediated by increased social connectedness out-group trust and inclusion of the out-group in the self.

\section{Method}

\section{Participants and Procedure}

One hundred and thirty eight participants initially participated in the study. Out of these, 5 were excluded due to missing data, 13 Greek participants were excluded because they thought of an immigrant that belonged to an out-group, 10 non-Greek participants were excluded because they thought of an in-group immigrant and 11 because they thought of an out-group immigrant. Therefore, the total sample consisted of 99 Greek participants, who all thought of an in-group immigrant abroad. Ages ranged between 18 and 46 years $(\mathrm{M}=23.06, \mathrm{SD}=5.44)$. The sample consisted of 60 males and 38 females. Participants were assigned to one of two conditions: (a) the control or (b) the nostalgia condition. All participants were given instructions that were adapted from previous studies (Hepper et al., 2012; Turner et al., 2013). They were all asked to recall an interaction with a Greek immigrant they know well, who has emigrated from Greece to another country, and right down their first name.

Participants in the nostalgia condition read the Oxford Dictionary's definition of nostalgia, along with some words linked with the word nostalgia (e.g., reminiscence, 


\section{European Journal of Social Psychology}

Nostalgia and prejudice reduction

familiar smells, feeling happy, longing). Then they were asked to think and write down in their own words a nostalgic event they had experienced that involved an interaction with the immigrant person identified earlier. The event had to be characterized by at least five of the words linked with nostalgia. They were asked to either include the five relevant words they chose in the description, or to circle them.

Participants in control condition were told that the study was on autobiographical memory. They were asked to think of and describe an ordinary event that involved interacting with the person they had previously identified, by including an objective record of that event. Following the conditions, participants filled in the manipulation check items in accordance to previous literature (Turner et al., 2012; 2013). At the end, all participants were asked to complete the questionnaire containing the dependent measures.

Materials

Participants were initially asked to complete questions regarding demographic information (e.g., their gender and the gender of the close immigrant, their ethnicity, age, how many years they have known the close immigrant and how close they felt to that person).

Social Connectedness

For social connectedness, participants were asked to indicate how much they agree with the following four items (based on Hepper et al., 2012), “Thinking about this interaction”: “...makes me feel protected,” “...makes me feel loved,” “...makes me feel connected to loved ones," and “...makes me feel I can trust others” (1=strongly disagree, $7=$ strongly agree) $\alpha=.83$.

Inclusion of the Out-group in the Self (IOGS) 
Nostalgia and prejudice reduction

To measure IOGS, participants were asked to indicate how close they feel to immigrants in general by choosing one of seven pairs of circles (adapted from Aron, Aron, $\&$ Smollan, 1992). The pairs of circles varied in their degree of overlap, from no overlap at all to almost full overlap. The greater the overlap between the circles the greater the IOGS score is ( $1=$ no overlap, $6=$ full overlap $)$.

Out-group Trust

Five items measured trust (based on Tam, Hewstone, Kenworthy, \& Cairns, 2009). Items (e.g., "Right now, I am able to trust an immigrant as much as any other person", "Do you think most immigrants would try to take advantage of you if they got the chance, or would they try to be fair?") were assessed on a 7-point Likert scale (1= strongly disagree, $7=$ strongly agree), $\alpha=.89$.

Out-group Attitudes

Participants were asked to indicate on a 7-point scale how they felt about immigrants in general right now, using four bipolar items (positive-negative, friendlyhostile, respect-contempt, admiration-disgust) (based on Wright et al., 1997), $\alpha=.91$.

\section{Manipulation Check Items}

The effectiveness of the nostalgia manipulation was assessed via three items (based on Wildschut et al., 2006; Zhou et al, 2012). The items were: "Right now, I am feeling quite nostalgic," "Right now I am having nostalgic feelings" and "I feel nostalgic at the moment" (1=strongly disagree, $7=$ strongly agree $), \alpha=.96$.Furthemore, following previous literature by Turner et al $(2012 ; 2013)$ on nostalgia and attitudes, we assessed the perceived typicality of and positivity toward the selected in-group member. In order to 


\section{European Journal of Social Psychology}

Nostalgia and prejudice reduction

assess the typicality of the selected in-group member, participants were asked to rate how typical they perceive this individual to be compared to immigrants in general on two items: "How typical do you think this person is of immigrants in general?" and "How representative do you think this person is of immigrants in general?" $(1=$ not at all, $7=$ very much), $\mathrm{r}=.67, \mathrm{p}<0.001$

Participants also rated the positivity toward the selected out-group member on two items: "How much do you like this individual?" (1=not at all, 7=very much), and "How positive is your attitude towards this individual?" ( $1=$ not at all positive, $7=$ very positive), $\mathrm{r}=.81$, $\mathrm{p}<.001)$.

\section{Results}

Preliminary analyses

Out of the 60 male participants, 15 thought of a female and 45 of a male immigrant. Out of the 38 female participants, 14 thought of a male and 24 of a female immigrant. $56 \%$ of participants rated their relationship with the chosen in-group immigrant as "Close", $40 \%$ reported it to be "Very Close" and 4\% reported the relationship to be "Not at all close". Participants' years of knowing the close immigrant varied between 1 and 26 years $(\mathrm{M}=12.40, \mathrm{SD}=7.74)$.

There was a significant main effect of gender on nostalgia $\left[\mathrm{F}_{(1,96)}=7.43, \mathrm{p}<0.01\right)$, social connectedness $\left[\mathrm{F}_{(1,96)}=15.07, \mathrm{p}<0.001\right)$ and trust $\left[\mathrm{F}_{(1,96)}=5.49, \mathrm{p}<0.05\right)$ with women demonstrating higher scores on all three variables than men. There were no interaction effects between experimental condition and gender on any of the dependent variables.

\section{Manipulation checks}


Nostalgia and prejudice reduction

Three one-way between subjects ANOVAs were carried out to examine the effect of condition (nostalgia/control) on each DV (nostalgia, positivity and typicality of the selected in-group member). As predicted, participants were more nostalgic in the nostalgia condition $(\mathrm{M}=4.7, \mathrm{SD}=1.3)$ than in the control group $(\mathrm{M}=3.6, \mathrm{SD}=2.0), \mathrm{F}_{(1,96)}=11.82$, $\mathrm{p}=0.001)$.

Data analysis further demonstrated no significant condition effect on the perceived positivity of the selected in-group immigrant ( $p>.05)$. There was though a significant effect of condition on typicality of the selected in-group member, $\left[\mathrm{F}_{(1,96)}=13.69 \mathrm{p}<.001\right]$.

Participants in the nostalgic group condition scored higher on typicality of the selected ingroup member $(\mathrm{M}=4.43, \mathrm{SD}=1.30)$ than those in the control condition $(\mathrm{M}=3.69, \mathrm{SD}=1.26)$. Therefore, typicality was further included in the main analysis as a covariate.

\section{Dependent measures}

A one-way MANCOVA was carried out to examine the effects of nostalgia on DVs (social connectedness, out-group trust, out-group attitudes and inclusion of the self in the out-group), controlling for typicality. Data analysis demonstrated a significant multivariate effect of condition group on all dependent variables [Wilk's Lamba=0.76, F $(4,93)=7.25$, $\mathrm{p}<.001]$. ANOVAs performed on each dependent variable separately showed a significant effect of condition on all DVs, social connectedness $[\mathrm{F}(1,96)=16.19, \mathrm{p}<.001]$, trust $[\mathrm{F}(1,96)$ $=17.39, \mathrm{p}<.001]$, IOGS $[\mathrm{F}(1,96)=16.36, \mathrm{p}<.001]$ and attitudes $[\mathrm{F}(1,96)=9.50, \mathrm{p}<.01]$. Means and standard deviations in the two conditions can be found in Table1.

\section{Mediational Analyses}

Correlations between the dependent variables can be found in Table 2. To explain the effect of nostalgia on overall out-group attitudes, we hypothesized a serial mediation model, whereby nostalgia increases a sense of social connectedness, which in turn predicts 


\section{European Journal of Social Psychology}

Nostalgia and prejudice reduction

higher levels of IOGS and out-group trust. IOGS and out-group trust, in turn, are expected to predict a more positive overall attitude towards immigrants (Figure 1). We tested this serial mediation model using PROCESS for SPSS, Model 6. We dummy coded the independent variable $(0=$ control condition, $1=$ nostalgia condition $)$.

As shown in Figure 1, the positive, direct effect of nostalgia on overall out-group attitude was mediated by social connectedness, IOGS but not by out-group trust. As expected, nostalgia increased social connectedness, which then predicted higher levels of IOGS and more positive out-group attitudes. Bootstrapping estimates (based on 5,000 bootstrap samples) indicated significant indirect effects of nostalgia on overall out-group attitudes via social connectedness and IOGS ( $\beta=0.23$, CI: $0.09 ; 0.48)$, as well as via IOGS only $(\beta=0.44$, CI: $0.09 ; 0.84)$. Social connectedness did not mediate the effect of nostalgia and out-group trust on out-group attitudes $(\beta=0.02, \mathrm{CI}$ : $-0.03 ; 0.11)$. The initial significant positive relationship between nostalgia condition and out-group attitudes $(\beta=0.87 ; 95 \%$ CI: $0.29 ; 1.37)$ became non-significant when all mediators were included in the model $(\beta=$ 0.04; 95\% CI: $-0.43 ; 0.51)$. All tested mediated paths with PROCESS Model 6 can be found in Table 3 .

\section{Discussion}

Limited research has examined the effect of nostalgia on improving intergroup processes. This is the first study that tested the effects of nostalgia on improving attitudes toward immigrants. Results showed that participants who recalled a nostalgic event with a close in-group immigrant reported greater social connectedness, IOGS, trust and improved attitudes toward immigrants in general, in comparison to the control condition where participants simply recalled an interaction with a close in-group immigrant without induced nostalgia. Importantly, we showed that the positive effects of nostalgia about a close in-group member (in this case, a Greek person), who shares an identity with the out- 
Nostalgia and prejudice reduction

group (being an immigrant), can generalize to the out-group as a whole (immigrants in general). We argue that this is crucial because in a context of high anxiety and threat like that between immigrants and host communities in some countries, asking people to recall nostalgic experiences with out-group members may not be realistic or achievable.

Therefore, prejudice reduction efforts can maximize on the use of nostalgia by placing it in the context of in-group members who share experiences or identities with the out-group.

The results of this study are in line with previously reported findings by Turner et al. $(2012 ; 2013)$, who explored the effects of nostalgia on attitudes toward overweight people and people with mental health issues. By focusing on immigration attitudes we demonstrated that nostalgia can be an effective tool for reducing prejudice, even in a context of high threat and negativity toward the out-group (that is, immigrants in Greece).

The mechanisms explaining the effect of nostalgia on out-group attitudes were further tested. We focused on the underlying role of social connectedness, IOGS and trust. Replicating Turner et al.'s (2013) mediation model, our research showed that increased social connectedness as a result of nostalgia led to higher levels of out-group trust and IOGS. Enhanced IOGS then led to more positive out-group attitudes. The role of social connectedness as a mediator of the nostalgia - IOGS - attitudes path supports a major function of nostalgia, that of enhancing an "expansive" state of mind that prompts people to form new relationships (Stephan et al., 2011). IOGS was the strongest predictor of positive attitudes toward immigrants following nostalgia, and acted by itself as a mediator of the effects. Trust, although affected by nostalgia, did not act as mediator in any of the above tested relationships. This is contrary to our initial predictions, it can however, be explained when looking at the specific socioeconomic context where the study took place. In an intergroup context characterized be increased levels of (realistic and symbolic) threat, trust, although affected by our manipulation, does not predict improved out-group 


\section{European Journal of Social Psychology}

Nostalgia and prejudice reduction

attitudes. IOGS, on the other hand, acts as the proximal mediator.

The above findings are in line with previous research that has demonstrated that

IOGS is a mediator in the relationship in between nostalgia and out-group attitudes (Turner et al., 2012; 2013). Arguably, the psychological mechanisms that underline the relation between nostalgia and prejudice reduction are not just a function of the groups that have been studied. By reminiscing nostalgically about a past encounter with a close other, individuals are prompted to re-engage in high-level evaluations of the self in relation to others, a process that has positive consequences for the individual's actions and perceptions in the present. This process may trigger prejudice reduction in two ways. It can induce decategorization such that intergroup boundaries (for example, between host society and immigrants) are no longer meaningful (Brewer \& Miller, 1984). Alternatively, it can stimulate the creation of a superordinate identity that is inclusive enough to encompass in-group and out-group members (Gaertner \& Dovidio, 2000). A close examination of the exact categorization processes underlying nostalgia can provide a fruitful future research avenue.

Although in this study we included mediators that have been highlighted in the relevant literature there might be other processes that can underlie the positive effects of nostalgia and that were not included here. Future research can look into the role of empathy, for example, as a proximal psychological process that can account for the reduction of prejudice following nostalgia (Pettigrew \& Tropp, 2008).

We further run manipulation checks in line with Turner et al. (2012; 2013). As predicted, it was found that participants in the nostalgia condition scored higher on nostalgia than those allocated in the control group. No differences were reported by participants in terms of the perceived positivity of the chosen immigrant. Results, however, 
Nostalgia and prejudice reduction

indicated that participants in the nostalgic group condition rated their chosen immigrant as being more typical of immigrants in general in comparison to the control condition. When typicality of the selected immigrant was included in the main analysis as a covariate the significant results remained. The present results supported the findings by Turner et al. (2013), who also found that even when perceived positivity and typicality of the selected immigrant were added to the analysis, participants in the nostalgia condition still scored higher on positive attitudes.

An additional strength of the present manipulation, which has only scarcely been used in previous studies, is that participants in both conditions were asked to first identify the name of the immigrant person and then were allocated to the experimental and control condition. The same procedure was conducted in one the studies published by Turner et al. (2013). In the experimental condition we further provided instructions on words that are linked with nostalgia. The meaning of the word nostalgia was also provided to ensure that all participants acquire knowledge of the word. The main advantage of this method is that it removes demand characteristics by eliminating what nostalgia should feel like, which further strengthens our basic premise here regarding the effectiveness of nostalgia as a prejudice reduction intervention.

We also recognize a number of limitations in the present research. Participants' attitudes towards the immigrants in general were not tested at baseline level before the experimental manipulation. Mean attitude scores in our sample, in fact, do not point to high levels of negativity. Participants in both conditions demonstrated relatively neutral overall attitudes towards immigrants. Our sample composed of University students who, in terms of social attitudes, are not always representative of the general population and could arguably be more open to positive intergroup representations (Smeekes et al., 2015). 


\section{European Journal of Social Psychology}

Nostalgia and prejudice reduction

Future studies need to further investigate these effects with community samples.

Recent European social survey data demonstrated a general negative tendency toward immigrant out-groups with an increase in the Greek population from 2002 to 2011 to be in favor of rejecting immigrants, to view them as a collective threat for life in their country and to feel that the cultural homogeneity of the nation is in danger (Iliou, 2014). Future research can further assess more specific views about some the most dominant immigrant groups residing in Greece, or any other country that hosts immigrants, at the moment (e.g., Albanians, Syrians, Pakistanis). This can shed light on differential attitudes based on the distinct characteristics of the immigrant groups.

Future research can also delve into the psychological and social ideological moderators of the effects of nostalgia on prejudice. Our study, for example, did not assess national nostalgia (i.e., the longing for how one's nation used to be in the past) or participants' political orientation (e.g.. support for left or right wing political parties), both of which could act as moderators of the nostalgia effects on prejudice. In the recent study by Smeekes et al. (2015), for instance, national nostalgia had positive implications for the national in-group but negative ramifications for the evaluation of immigrant out-groups. A future study could further do a more qualitative analysis of the categories of the words listed by participants in their nostalgic narratives.

The findings of our research have a number of practical implications. When considering prejudice reduction interventions, nostalgia about past encounters is easier to implement and probably more sustainable than other strategies. If the present findings are extended and generalized across different intergroup settings, then nostalgia can be an invaluable construct in the field of prejudice reduction. Findings thus far are promising, and this study could be important in the efforts of governmental and non-governmental 
Nostalgia and prejudice reduction

organizations' campaigns to tackle prejudice in the ever changing societal context of western societies. In addition, the findings of our research can inform psychoeducational interventions in educational and community settings, especially when implemented alongside other prejudice reduction methods in carefully evaluated programs. 
Nostalgia and prejudice reduction

\section{References}

Afouxenidis, A., Sarris, N., \& Tsakiridi, O. (2012). Integration of immigrants:Perceptions, practical, politics. Athens: National Centre for Social Research.

Allport, G. W. (1954). The nature of prejudice. Cambridge, MA: Perseus Books.

Angermeyer, M. C. (2006). Public beliefs about and attitudes towards people with mental illness: A review of population studies. ACTA Psychiatrica Scandinavica, 113, 163-179. doi: 10.1111/j.1600-0447.2005.00699.

Aron, A., Aron, E. N., \& Smollan, D. (1992). Inclusion of other in the self scale and the structure of interpersonal closeness. Journal of Personality and Social Psychology, 63, 596-612. doi: 10.1037/0022-3514.63.4.596.

Aron, A., Aron, E. N., Tudor, M., \& Nelson, G. (1991). Close relationships as including other in the self. Journal of Personality and Social Psychology, 60, 241-253.

Austin, N. (2010). Homeric nostalgia. The Yale Review, 98, 37-64. doi: 10.1111/j.14679736.2010.00598.

Backer, S. M., \& Kennedy, P. F. (1994). Death By Nostalgia: a Diagnosis of ContextSpecific Cases. Advances in Consumer Research, 21, 169-174.

Bassett, J., \& Connelly, N. J. (2011). Terror Management and Reactions to Undocumented Immigrants: Mortality Salience Increases Aversion to Culturally Dissimilar Others. The Journal of Social Psychology, 151(2), 117-120. doi:10.1008/00224540903365562.

Batson, C. D., Polycarpou, M. P., Harmon-Jones, E., Imhoff, H. J., Mitchener, E. C., Bednar, L. L., Klein, T. R., \& Highberger, L. (1997). Empathy and attitudes: Can feeling for a member of a stigmatized group improve feelings toward the group? Journal of Personality and Social Psychology, 72(1), 105-118. doi: 10.1037/0022- 
Nostalgia and prejudice reduction

3514.72.1.105.

Boym, S. (2001). The future of nostalgia. New York, NY: Basic Books.

Brewer, M. B., \& Miller, N. (1984). Beyond the contact hypothesis: Theoretical perspectives on desegregation. In N. Miller \& M. B. Brewer (Eds.), Groups in contact: The psychology of desegregation, 281-302. Orlando, FL: Academic Press.

Briggs, L., \& Osman, L. O. (2010). Types of Victimization Experienced hy Men and Women That Influence Rape Empathy. Psi Chi, The International Honor Society in Psychology, 15, 30-33.

Brown, R., \& Hewstone, H. (2005). An integrative theory of intergroup contact. Advances in Experimental Social Psychology, 37, 255-343. doi: 10.1016/S00652601(05)37005-5.

Byrne, D. (1971). The attraction paradigm. New York: Academic Press.

Castelnuovo-Tedesco, P. (1980). Reminiscence and nostalgia: The pleasure and pain of remembering. In S. I. Greenspan \& G. H. Pollack (Eds.), The course of life: Psychoanalytic contributions toward understanding personality development. Adulthood and the aging process, 3, 104-118.

Cheung, W., Wildschut, T., Sedikides, C., Hepper, E., G., Arndt, J., \& Vingerhoets, A., J., J., M. (2013). Back to the Future Nostalgia Increases Optimism, Personality and Social Psychology Bulletin, 39 (11), 1484-1496. doi: 10.1177/0146167213499187.

Cholezas, I., \& Tsakloglou, P. (2009). The Economic Impact of Immigration in Greece: Taking Stock of the Existing Evidence. Southeast European and Black Sea Studies 9, 77-104. doi: 10.1080/14683850902723439 


\section{European Journal of Social Psychology}

Nostalgia and prejudice reduction

Cordaro, F. (2011). The relationship between nostalgia, social exclusion, and empathy. University of Southampton, Psychology, Doctoral Thesis, p94.

Crisp, R. J., \& Turner, R. N. (2009). Can imagined interactions produce positive perceptions? Reducing prejudice through simulated social contact. American Psychologist, 64, 231-240. doi: 10.1037/a0014718.

Davis, F. (1979). Yearning for yesterday: A sociology of nostalgia. NY: Free Press.

Dovidio, J. F., Gaertner, S. L., Kawakami, K., \& Hodson, G. (2002). Why can't we just get along? Interpersonal biases and interracial distrust. Cultural Diversity and Ethnic Minority Psychology, 8, 88-102. doi:10.1037/1099-9809.8.2.88.

Eurostat (2016). Migration and migrant population statistics. Retrieved from http://www.npr.org/2011/08/14/139613525/tensions-over-illegal-immigrants-ingreece-rises.

Festinger, L. (1954). A theory of social comparison processes. Human Relations, 7, 117-140.

Figgou, L., Sapountzis, A., Bozatzis, B., Gardikiotis, A., \& Pantazis, P. (2011). Constructing the stereotype of immigrants' criminality: Accounts of fear and risk in talk about immigration to Greece. Journal of Community \& Applied Social Psychology, 21(2), 164-77. doi: 10.1002/casp.1073

Fisher, S. (1989). Homesickness, cognition, and health. London, U.K.: Erlbaum.

Frost, I. (1938). Homesickness and immigrant psychoses. Journal of Mental Science, 84, $801-847$.

Gaertner, S. L., \& Dovidio, J. F. (2000). Reducing intergroup bias: The common in-group identity model. Philadelphia, PA: Psychology Press. doi: $10.1177 / 1368430201004004001$ 
Nostalgia and prejudice reduction

González, R., \& Brown, R. (2006). Dual identities in intergroup contact: Group status and size moderate the generalization of positive attitude change. Journal of Experimental Social Psychology, 42, 753-767. doi: 10.1016/11.008.

Greene, R. (1991). Is there an alternative to peer review?, Behavioral and Brain Sciences, 14(1), 149-50.

Greenberg, J., Pyszczynski, T., \& Solomon, S. (1986). The causes and consequences of the need for self-esteem: A terror management theory. Public self and private self, 189-212. NY: Springer. doi: 10.1007/978-1-4613-9564-5_10.

Havlena, W. J. \& Holak, S. L. (1991). The good old days: Observations on nostalgia and its role in consumer behavior. Advances in Consumer Research, 323-329.

Hepper, E., G., Ritchie, T. D., Sedikides, C., \& Wildschut, T. (2012). Odyssey's end: Lay conceptions of nostalgia reflect its original Homeric meaning. Emotion, 12(1), 10219. doi: $10.1037 / \mathrm{a} 0025167$.

Hepper, E. G., Wildschut, T., Sedikides, C., Ritchie, T. D., Yung, Y. F., Abakoumkin, G., Abdollahi, A., \& Zhou, X. (2013). Lay conceptions of nostalgia across cultures. Unpublished manuscript, University of Southampton.

Hewstone, M., \& Greenland, K. (2000). Intergroup conflict. International Journal of Psychology, 35(2), 136-144. doi:10.1080/002075900399439.

Holbrook, M. B. (1993). Nostalgia and consumption preferences: Some emerging patterns of consumer tastes. Journal of Consumer Research, 20, 245-256. doi:10.1086/209346.

Hutcherson, C. A., Seppala, E. M., \& Gross, J. J. (2008). Loving-kindness meditation increases social connectedness. Emotion, 8(5), 720-724. doi:10.1037/a0013237

Iliou K. (2014). Personal perceptions and political affiliations shaping immigration attitudes in times on fisceral austerity: The case of Greece. In N. P. Petropoulos, G. 
Nostalgia and prejudice reduction

O. Tsobanoglou. (Eds). The debt crisis in the Eurozone: Social impacts. Newcastle upon Tyne: Cambridge Scholars Publishing.

Juhl, J., Routledge, C., Arndt, J., Sedikides, C., \& Wildschut, T. (2010). Fighting the future with the past: Nostalgia buffers existential threat. Journal of Research in

Personality, 44, 309-314. doi:10.1016/j.jrp.2010.02.006.

Kakissis, I. (2014). "Tensions rise over illegal immigrants in Greece". Retrieved from http://www.npr.org/2011/08/14/139613525/tensions-over-illegal-immigrants-ingreece-rises.

Kaplan, H. (1987). The psychopathology of nostalgia. Psychoanalytic Review, 74, 465486.

Kapsalis, A. (2005). The right to stay and immigrants' employment. Migration Policy and Immigrants' Rights, 22, 55-70. (In Greek)

Kapsalis, A., \& Linardos-Rylmon., P. (2005). The Greek migration policy. Report and suggestions from Trade Unions point of view. Migration Policy and Immigrants' Rights, 22,11-27. (In Greek)

Karydis, V. (2004). The second generation issue: Crime and immigration. Greece of immigration: Social participation, rights and citizenship, 205-232. (In Greek)

Li, Y. (2015). Nostalgia Promoting Pro-Social Behavior and Its Psychological Mechanism, Journal of Social Sciences, 3(10), 177-186. doi: 10.4236/jss.2015.310024.

McCann, W. H. (1941). Nostalgia: A review of the literature. Psychological Bulletin, 38, 165-182. doi:10.1037/h0057354.

McDermott, S. (2002). Memory, nostalgia and gender in a thousand acres. Signs, 28, 406. doi: $10.1086 / 340916$. 
Nostalgia and prejudice reduction

Mills, M. A., \& Coleman, P. G. (1994). Nostalgic memories in dementia: A case study. International Journal of Aging and Human Development, 38, 203-219. doi: 10.2190/NCAJ-0G0L-VTQ4-V1L8.

Pettigrew, T. F., \& Tropp, L. R. (2006). A meta-analytic test of intergroup contact theory. Journal of Personality and Social Psychology, 90, 751-783. doi: 10.1037/00223514.90.5.751.

Pettigrew, T. F., \& Tropp, L. R. (2008). How does intergroup contact reduce prejudice? Meta-analytic tests of three mediators. European Journal of Social Psychology, 38, 922-934. doi: 10.1002/ejsp.504.

Preacher, K.J., \& Hayes A. F. (2008). Asymptotic and resampling strategies for assessing and comparing indirect effects in multiple mediator models. Behavior Research Methods, 40 (3), 879-891. doi: 10.3758/BRM.40.3.879.

Reisenwitz, H. T., Iyer, R., \& Cutler, B. (2004). Nostalgia, advertising and the influence of nostalgia proneness. Marketing Management, 55-66.

Robolis, S. (2005). Economy, Labour Market and Immigration in Greece. Migration Policy and Immigrants' Rights, 22, 29-43.

Rosen, G. (1975). Nostalgia: A “forgotten” psychological disorder. Psychological Medicine, 5, 340-354. doi: 10.1017/S003329170005697.

Routledge, C., Arndt, J., Sedikides, C., \& Wildschut, T. (2008). A blast from the past: The terror management function of nostalgia. Journal of Experimental Social Psychology, 44, 132-140. doi: 10.1016/j.jesp.2006.11.001.

Routledge, C., Arndt, J., Wildschut, T., Sedikides, C., Hart, C. M., Juhl, J., Vingerhoets, A. J., \& Schlotz, W. (2011). The past makes the present meaningful: Nostalgia as an existential resource. Journal of Personality and Social Psychology, 101, 638-652. doi: 10.1037/a0024292. 


\section{European Journal of Social Psychology}

Nostalgia and prejudice reduction

Sapountzis, A., Figgou, L., Bozatzis, N., Gardikiotis, A., \& Pantazis, P. (2013). Categories we share: Mobilising common in-groups in discourse on contemporary immigration in Greece. Journal of Community \& Applied Social Psychology, 23, 347-361. doi: $10.1002 /$ casp. 2128

Secretariat of Population and Societal Cohesion, (2012) (Online) Available at: http://www.ypes.gr/el/Generalsecretariat_PopulationSC/.

Sedikides, C., Wildschut, T., Arndt, J., \& Routledge, C. (2008). Nostalgia: Past, present and future. Current Directions in Psychological Science, 17, 304-307. doi: $10.1111 / \mathrm{j} .1467-8721.2008 .00595$.

Sedikides, C., Wildschut, T., \& Baden, D. (2004). Nostalgia: Conceptual issues and existential functions. In J. Greenberg, S. Koole, \& T. Pyszc- zynski (Eds.), Handbook of experimental existential psychology, 200-214. NY: Guilford.

Sedikides, C., Wildschut, T., Routledge, C., Arndt, J., \& Zhou, X. (2009). Buffering acculturative stress and facilitating cultural adaptation: Nos- talgia as a psychological resource. In R. S. Wyer, Jr., C.-Y. Chiu, \& Y.-Y. Hong (Eds.), Understanding culture: Theory, research, and application, 361-378. NY: Psychology Press.

Seehusen, J., Cardaro, F., Wildschut, T., Sedikides, C., Routledged, C., Blackharte, G., . . . Vingerhoets, M. (2013). Individual differences in nostalgia proneness: The integrating role of the need to belong. Personality and Individual Differences, 55(8), 904-908. doi: 10.1016/j.paid.2013.07.020.

Shaver, P., Schwartz, J., Kirson, D., \& O’Connor, C. (1987). Emotion knowledge: Further exploration of a prototype approach. Journal of Personality and Social Psychology, 52, 1061-1086. doi: 10.1037/0022-3514.52.6.1061. 
Nostalgia and prejudice reduction

Sherman, E., \& Newman, E. S. (1977). The meaning of cherished personal Possessions for the elderly. The International Journal of Aging and Human Development,8(2), 18192. doi: 10.2190/M1H4-2NTB-92GA-AK32.

Smeekes, A., Verkuyten, M., \& Martinovic, B. (2015). Longing for the country's good old days: National nostalgia, autochthony beliefs, and opposition to Muslim expressive rights. British Journal of Social Psychology, 54(3), 561-580. doi: 10.1111/bjso. 12097 .

Stephan, E., Sedikides, C., Wildschut, T., Routledge, C., Zhou, X., Kuang, L., \& Vingerhoets, A. J. J. M. (2011). Nostalgia regulates avoidance and approach motivation. Unpublished manuscript, University of Southampton.

Sterba, E. (1940). Homesickness and the mother's breast. Psychiatric Quarterly, 14, 701707. doi: 10.1007/BF01566790.

Stren, B. (1992). Historical and personal nostalgia in advertising text: The Fin De Siecle effect. Journal of Advertising, 31, 11-22. doi: 10.1080/00913367.1992.10673382.

Stroebe, M., van Vliet, T., Hewstone, M., \& Willis, H. (2002). Homesickness among students in two cultures: Antecedents and consequences. British Journal of Social Psychology, 93, 147-168. doi: 10.1348/000712602162508.

Tam, T., Hewstone, M., Kenworthy, J., \& Cairns, E. (2009). Intergroup trust in Northern Ireland. Personality and Social Psychology Bulletin, 35, 45-49. doi: $10.1177 / 0146167208325004$.

Tajfel, H. (1982). Social psychology of intergroup relations. In M. R. Rosensweig \& L. W. Porter (Eds.), Annual Review of Psychology, 33, 1-39. Palo Alto, CA: Annual Reviews. doi: 10.1146/annurev.ps.33.020182.000245.

Tajfel, H., Billig, M. G., Bundy, R. F , \& Flament, C. (1971). Social categorisation and intergroup behavior. European Journal of Social Psychology, 1, 149-177. 
Nostalgia and prejudice reduction

Triandafyllidou, A., \& Ambrosini, M. (2011). Irregular immigration control in Italy and Greece: Strong fencing and weak gate-keeping serving the labour market. European Journal of Migration and Law, 13, 251-73. doi: $10.1163 / 157181611 X 587847$

Tsitselikis, K. (2013). Sticks, Not Carrots: Immigration and rights in Greece and Turkey. Southeast European and Black Sea Studies, 13(3), 421-34. (In Greek)

Turner, R. N., Hewstone, M., Swart, H., Tam, T., Myers, E., \& Tausch, N. (2010). Promoting intergroup trust among adolescents and young adults. In K. Rotenberg (Ed.), Interpersonal trust during childhood and adolescence, 295-321. Cambridge, England: Cambridge University Press.

Turner, R. N., Wildschut, T., \& Sedikides, C. (2012). Dropping the weight stigma: Nostalgia improves attitudes toward persons who are overweight. Journal of Experimental Social Psychology, 48, 130-137. doi: 10.1016/j.jesp.2011.09.007.

Turner, N., R., Wildschut, T., Sedikides, C., \& Gheorghiu, M. (2013). Combating the mental health stigma with nostalgia. European Journal of Social Psychology, 43, 413-422. doi: 10.1002/ejsp.1952.

Uzefovsky, F., Israel, S., Perach-Barzilay, N., Shamay-Tsoory, S. G., Shalev, I., Edelman, S., Raz, Y., Mankuta, D., \& Knafo, A. (2014). The Dopamine D4 receptor gene shows a gender-sensitive association with cognitive empathy: Evidence from two independent samples. Emotion, 14 (4), 712-721. doi:10.1037/a0036555.

Van Tilburg, M. A. L. \& Vingerhoets, A. J. J. M. (2005). Psychological aspects of geographical moves. Homesickness and acculturation stress. Amsterdam, The Netherlands: Amsterdam University Press. 
Nostalgia and prejudice reduction

Walsh, A., \& Walsh, P. (1986). The effects of immigration, stigma, and stress on biological effective blood pressure levels. International Review of Modern Sociology, 16(2), 353-365.

Wildschut, T., Sedikides, C., Arndt, J., \& Routledge, C. (2006). Nostalgia: Content, Triggers, Functions. Journal of Personality and Social Psychology, 9 (15), 975-93. doi: $10.1037 / 0022-3514.91 .5 .975$.

Wright, S. C., Aron, A., McLaughlin-Volpe, T., \& Ropp, S. A. (1997). The extended contact effect: Knowledge of cross-group friendships and prejudice. Journal of Personality and Social Psychology, 73, 73-90. doi: 10.1037/0022-3514.73.1.73.

Zhou, X., Sedikides, C., Wildschut, T., \& Gao, D. G. (2008). Counteracting loneliness: On the restorative function of nostalgia. Psychological Science, 19, 1023-1029. doi: 10.1111/j.1467-9280.2008.02194. 
Table 1.

Means and standard deviations of the effects of condition on the dependent variables and the manipulation check measures.

\begin{tabular}{llllll}
\hline & \multicolumn{2}{l}{ Nostalgia } & \multicolumn{3}{l}{ Control } \\
& $\mathrm{M}$ & $\mathrm{SD}$ & $\mathrm{M}$ & $\mathrm{SD}$ & F Value \\
\hline IOGS & 4.79 & 1.23 & 3.52 & 1.59 & $17.14^{* * *}$ \\
Social & 4.75 & 1.15 & 3.80 & 1.33 & $15.19^{* * *}$ \\
Connectedness & & & & & \\
Outgroup Trust & 4.40 & 1.13 & 3.55 & 1.10 & $14.78^{* * *}$ \\
Outgroup Attitudes & 5.41 & 1.10 & 4.53 & 1.60 & $8.43^{* *}$ \\
Nostalgia & 4.72 & 2.04 & 3.47 & 2.04 & $12.84^{* * *}$ \\
Typicality & 4.41 & 1.13 & 3.60 & 1.13 & $14.78^{* * *}$ \\
Positivity & 5.64 & 1.07 & 5.59 & 1.17 & $0.46^{*}$ \\
\hline
\end{tabular}

Note: $* \mathrm{p}>0.05, * * \mathrm{p}<0.01, * * * \mathrm{p}<0.001$ 
Table 2.

Correlations among variables.

\begin{tabular}{|c|c|c|c|c|c|c|}
\hline & Mean & SD & 1. & 2. & 3. & 4. \\
\hline 1. Attitude & 5.06 & 1.38 & 1 & $.318^{* *}$ & $.379^{* *}$ & $.646^{* *}$ \\
\hline 2. Trust & 4.07 & 1.12 & & 1 & $.463^{* *}$ & $.321^{* *}$ \\
\hline $\begin{array}{l}\text { 3. Social } \\
\text { Connectedness }\end{array}$ & 4.37 & 1.31 & & & 1 & $.401^{* *}$ \\
\hline 4. IOGS & 4.22 & 1.49 & & & & 1 \\
\hline
\end{tabular}

Note $* * \mathrm{p}<0.01$ level 


\section{Table 3.}

Indirect effects of nostalgia (independent variable) on outgroup attitudes (dependent variable) via hypothesized mediators.

\begin{tabular}{llll}
\hline Predictor & Indirect process & Criterion variable & $\begin{array}{l}95 \% \text { Bootstraped } \\
\text { CIs }\end{array}$ \\
Group & Social Connectedness & Outgroup Attitudes & -.09 to 0.32 \\
Group & IOGS & Attitudes & 0.09 to 0.84 \\
Group & Trust & Attitudes & -0.07 to 0.19 \\
Group & Social Connectedness, & Attitudes & 0.09 to 0.48 \\
& IOGS & & \\
Group & Social Connectedness, & Attitudes & -0.03 to 0.11 \\
& Trust & & \\
Group & IOGS, Trust & Attitudes & -.012 to 0.06 \\
\hline
\end{tabular}




\section{Figure 1.}

Mediation model showing social connectedness, IOGS and outgroup trust as consecutive mediators of the effect of nostalgia on outgroup attitudes.

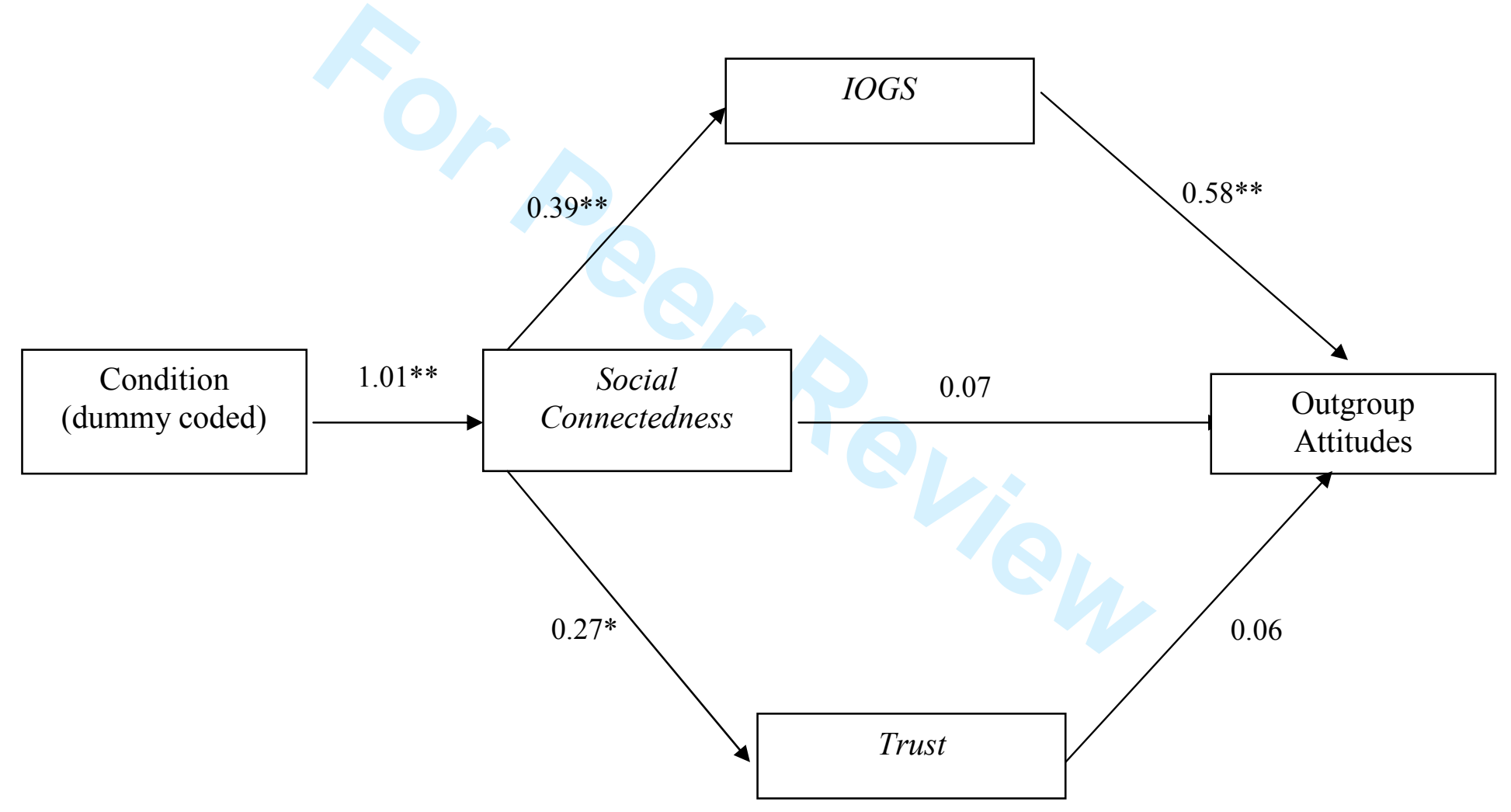

Note. $* \mathrm{p}<.05 ; * * \mathrm{p}<.001$. Unstandardized regression coefficients are reported and condition is dummy coded ( 0 for control and 1 for experimental). 